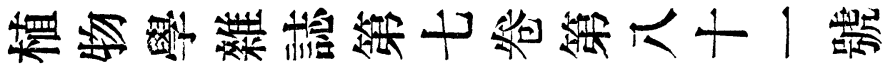

THE BOTANICAL MAGAZINE.

[Vol. VII.

November 10, 1893.

No. 81.]

\section{Tetraspores of Desmia.}

K. Okamura.

I am not certain whether the tetraspore of Desmia is already known or not. But as it is not described in J. Agardh's Sp. Alg vol. III. p. 354, I will here describe what I have seen in Desmia japonica

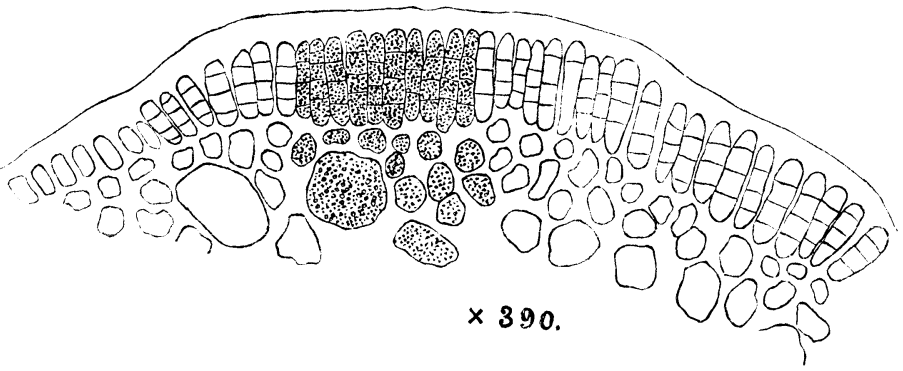
Haw., one of our common species in the warmer part of the Pacific coast. The tetraspores originate from minute colord cortical cellules forming roundish patches, which are often confluent and of a more or less irregular form. At first cortical cellules elongate and rise up above the surface of the frond forming a flat elevation, and afterwards each cellule is transformed by transverse partitions into a zonally divided tetraspore. It is oblong-cylindrical, $26-44 \mu$. 
Notes on Japaneic Plants, XX.

long, $\delta \mu$. broad, and almost colorless.

The specimens I have examined were collected on July 14, of this year Sugashima near Toba in the province of Shina.

\section{Notes on Japanese Plants, XX.}

Tomitarō Makino.

\section{ARACEÆ. てんろんしゃう科}

Arisaema sikokianum Franch. et Sav. Enum. pl. Jap. II. 6 et 507. Engl. in A. DC. Monogr. Phanerog. II. 560. Iinuma Sōmoku-Dusetsu XIX. fol. 2I. Nom. jap. Yukimochisō. ユキモチサロ

Leaf-segments 5 or 3 , entire, often variegated with white colour on the upper surface. Ovary onecelled; ovules 3-4. Spadix, ripe fruits conical, with darker purple colour on the surface. Berries numerous, scarlet, roundish-obconical, sessile, one-celled; seeds ovoid, smooth, I-2 or 3, stipitate; albumen copious; embryo cylindrical, staight.

Tosa: Sakawa-mura, Mt. Yokogura, Tadikawa-mura. (T. Makino).

$\beta$. serratum Makino. 